\title{
MULTILAYER RACISMS AS REPRESENTED IN ARUNDHATI ROY'S THE GOD OF SMALL THINGS
}

\author{
RASISME BERLAPIS DALAM NOVEL THE GOD OF SMALL THINGS \\ KARYA ARUNDHATI ROY
}

\author{
Dwi Fatmawati ${ }^{1}$, Irana Astutiningsih ${ }^{2 *}$ \\ ${ }^{1}$ Alumni of Faculty of Humanities, Universitas Jember \\ ${ }^{2}$ Faculty of Humanities, Universitas Jember \\ *Corresponding Author: irana.sastra@unej.ac.id \\ Informasi Artikel:
}

Dikirim: 29/7/2019; Direvisi: 11/10/2019; Diterima: 25/12/2019

\begin{abstract}
This article discusses racism in India as illustrated in Arundhati Roy's The God of Small Things. The novel contains racism issues in India in 19th century. In the novel, not only is racism experienced by coloured people as a result of white people discriminating them, but also among the coloured people themselves, experienced by those considered inferior based on caste. The research aims at figuring out how racism is constructed in The God of Small Things as well as knowing the ideological position of the author. Hence, Hall's representation theory is used in this research focusing on discursive approach. The result shows that the author criticizes racism and people's classification based on caste.
\end{abstract}

Keywords : caste, racism, representation

Abstrak

Artikel ini membahas isu-isu rasisme yang digambarkan di India dalam novel The God of Small Things karya Arundhati Roy. Novel ini mengandung banyak kasus rasisme yang terjadi di India pada abad ke sembilan belas. Disini diceritakan bahwa rasisme yang terjadi tidak hanya kepada orang kulit berwarna, namun rasisme di novel The God of Small Things terjadi juga kepada antar orang kulit berwarna yang dianggap inferior. Tujuan dari penelitian ini adalah untuk mengetahui bagaimana rasisme dikonstruksi di Novel The God of Small Things dan juga untuk mengetahui bagaimana posisi penulis dalam kasus rasisme yang terjadi di India. Merujuk ke alasan ersebut, teori representasi dari Stuart Hall dan discursive approach oleh Michel Foucault digunakan sebagai alat untuk menganalisa masalah diatas. Hasil dari kajian ini menunjukan bahwa si penulis novel mengkritik kasus rasisme dan pengelompokan masyarakat berdasarkan kasta masing-masing. Penulis novel The God of Small Things memprotes praktik rasisme dan juga menuntut kesetaraan hidup melalui karya sastra yang ditulisnya.

Kata kunci: kasta, rasisme, representasi 


\section{INTRODUCTION}

Racism always becomes the common conflict of social life that is found in literary work such as a novel. Racism still exists in the world as the world consists of many races. It also happens to Indian society where Indian considered as the inferior, and the superior is British. Wolf (2018) states that race is a socially constructed history dividing people into two categorizations, those are visual and biological differences. But these categorizations are formless and transformed over time which reflects their social rather than physical basis. It means that the racism that occurs nowadays is not only limited to skin color differences, but also non-visual differences such as the social class differences. That statement is connected with this research because racism in this research is not only about skin color differences but also social class differences. Grosfoguel (2016) states that racism is a grouping of humans into superiority and inferiority, where inferiority is considered inhuman or nonhuman and they cannot enjoy human rights, civil rights, women's rights, labor rights, etc. On the other hand, "racism is unfair treatment or dislike of somebody because they are of a different race" (Oxford Advanced Learner's Dictionary Fifth edition, 1995:957). So, multilayer racism is racism that does not only consist of one layer, because racism that accurs in The God of Small Things is racism which happen to India (asian race), and within India there is also racism issue that occured between social class differences (upper class to lower class).

The object of this research is a novel entitled The God of Small Things written by Arundhati Roy published in 1997. The God of Small Things novel received wide acceptance from its readers and became the best-selling novel at that time. In 1998 the novel was awarded The Man Booker Prize for Fiction (Tikkanen, 2019). The story begins with Rahel's return to Kerala to meet his twin brother Estha. Like a "homecoming" person, every return will surely arouse memories that have been hidden in the past. A dozen years ago, Rahel and Estha were separated because their extended family assumed that if they both remained together, then they would always cause new problems. When they were 7 years old, they were accused of guilty of the death of their cousin, Shopie Mol (she is a daughter of uncle Chacko and an English lady named Margareth). Sophie is a daughter who is greatly adored by Ammu's great family, solely because she is half English. Sophie Mol was drowned in the river when she, Estha, and Rahel decided to run away from home. The Twin's big family hate them not only because they are charged and found guilty for the death of Sophie Mol, but also because they are born from the diforced parents (Ammu and Baba), and moreover Baba is a Hindu, where Hinduism is a religion which is underestimated. Beside that, Paravan is also a group that gets unfair treatment. Paravan is an untouchable, which is underestimated by the Brahma (Jhajharia, 2018). Paravan got unfair treatment from Ammu's big family. They made a slave with a salary that is not worth it, they are also strictly forbidden to enter into Ammu's house. We have two previous researches, the first previous research is a thesis written by Warda (2017), entitled "Racism Faced by Minette Swift in Joyce Carol Oates's Black Girl/White Girl". The second previous research is also a thesis written by Galuh Rizki Winahyu (2017) entitled The Representation of Woman's oppression Through the Female Main Character in Zana Muhsen With Andrew Crofts's Sold. These two previous researches are really contributing us in writing this research. 


\section{METHOD}

Representation is a system or idea that enables people to deliver and understand a certain problems (Howarth, 2011). In this research, we use the representation theory written by Stuart Hall and it will be very helpful to support this research and discursive approach by Michel Foucault is also used as a tool to analyze the problem in this research. We use qualitative method for conducting this research. The primary data are taken from novel entitled The God of Small Things by Arundhati Roy, and the secondary data taken from other sources related to the topic discussion in this research. Therefore, close reading is needed in this research to find out and complete the answer of the research questions. The data are collected by technique of documentary and close reading to several sources.

In the way of processing the data, to relate the source data with the theory, there are several steps to do. The first step I have to read the novel many times. It is important to read the novel more than once because reading the novel in several times can be the best way to get a deep understanding of the content of the novel. Afterwards, the next step is to collecting and classifying the data as well as the sentences or quotations from the source data relating to the theory. The part one is talking about racism that occured between India and England in the novel. Then, the second is about racism that occured to Indian itself between Touchable and Paravan. The next, the activity goes to the analysis. In this case, after all data are collected and classified, the further step is to analyse them. The analysis which is done in this method of course based on the research questions that I have made. The first research question is about how the racism described in the novel. The second research question is about how was the social condition in Indian society as the contextual background. The next analysis focuses on how the critical position of the author toward racism which represents in the novel. In this analysis, to answer this question, I relate the discourse of racism in the text and racismin the context.

\section{DISCUSSION}

This chapter discusses racism in India in 1969 till 1993 as constructed by Arundhati Roy's The God of Small Things. This analysis uses Representation theory proposed by Stuart Hall to answer the relation between the discourse of racism in the novel and racism in society, and also to find out the critical position of the author. In this chapter, data that has been collected are analyzed to answer the research questions. First is how racism is described in Arundhati Roy's The God of Small Things, Second is how India's social condition in 1969 till 1993 was, and the last is what the critical position of the author about racism is. It necessitates some quotes to prove the existence of the issue.

\section{The Racisms as Represented in Arundhati Roy's The God of Small Things}

Racism in this novel becomes a central topic that will be discussed in this chapter. It is necessary to understand what racism is. According to Tyson (2006:360), "Racism refers to the unequal power relation that grow from the sociopolitical domination of one race by another and that result in systematic discriminatory practices, for example segregation, domination, and persecution." It usually happened between black and white people. Black people are 
considered as the inferior than white because of their coloured skin. However, racism nowadays is not only limited to skin color differences, but also non-visual differences such as the social class differences. As Wolf (2018) states that race is a socially constructed history that dividing people into two categorizations, those are visual and biological differences. But these categorizations are formless and transformed over time which reflects their social rather than physical basis.

\section{Racism between Asian race and European race}

Racism in The God of Small Things (TGST) (Roy, 1997) is racism that happens to Indians where Indians considered as the inferior and English people considered as the superior. Indians are very obsessed with white people. That obsession has been well known and has been practiced in everyday life. Indians assume that skin color determines a person's quality. They think that white people have positive connotations. On the contrary, black people have negative connotations (Beatty, 2018). It means that racism in India really happened in the real life. It is very clear that Indians consider white people more respectable than black people. These statements will be supported by several quotations in the novel.

"That whole week Baby Kochamma eavesdropped relentlessly on the twins' private conversations, and whenever she caught them speaking in Malayalam, she levied a small fine which was deducted at source. From their pocket money. She made them write lines- "impositions" she called them-I will always speak in English, I will always speak in English. A hundred times each" (TGST:6).

The quotations above show that Baby Kochamma assuming that English people are superior to Indians, therefore she chooses English to be spoken by the twins as the punishment they have to do. It shows that the condition in India constructed in the novel is reflection from the condition in the real life at that time. The author wrote this novel inspired from the real condition in India. It shows that literature cannot be separated from the real society. Based on Foucault, things mean something and "true", only within a specific historical context. He thinks that there would not be found the same phenomena across different historical period. Foucault thinks that in each period, discourse produced forms of knowledge, which differed radically from period to period (Hall, 1997:46).

"Well, actually there may be an option... perhaps we could work something out. Think positive, is what I always say. Count your blessings." Hollick paused to order a pot of black coffee. "You're a very lucky man, you know, wonderful family, beautiful children, such an attractive wife..." He lit a cigarette and allowed the match to burn until he couldn't hold it anymore. "An extremely attractive wife..." The weeping stopped. Puzzled brown eyes looked into lurid, red-veined, green ones. Over coffee Mr.Hollick proposed that Baba go away for a while. For a holiday.To a clinic perhaps, for treatment. For as long as it took him to get better. And for the period of time that he was away, Mr.Hollick suggested that Ammu be sent to his bungalow to be "looked after." Already there were a number of ragged, lightskinned children on 
the estate that Hollick had bequeathed on tea-pickers whom he fancied. This was his first incursion into management circles" (TGST:41—42).

The quotation above is an insult from Mr. Hollick to Ammu. He is an English man who own a tea plantation in Ayemenen. Furthermore, for his tea plantation, he recruits many Indians to work for his tea plantation. As he is the owner of the tea plantation, automatically, he has a social power upon his labours. When Baba makes a mistake, Mr. Hollick calls him and gives him some advices. Seemingly, what Mr. Hollick suggests to him is an effort for saving him away from getting fired, unfortunately, Mr. Hollick uses him for sleeping with Ammu. Mr. Hollick knows that Baba likes Ammu, so that he uses this condition to exploit Baba. In secret, Mr. Hollick has a hidden feeling to Ammu, he adores her beauty so much. As a powerful man who has full authority, he exploits the situation and turns it into a benefit for himself. So that he can successfully achieves what he want from Baba and Ammu. This phenomenon is seen as a power of Western people as 'superior' and Eastern people, especially Indians as 'inferior'. Indeed, what Mr. Hollick did to Indians in this novel is considered as an arbitrary attitude.

"There would be two flasks of water. Boiled water for Margaret Kochamma and Sophie Mol, tap water for everybody else" (TGST:46).

The quotation above reminds me to Edward Said's Orientalism study. They brought two different kinds of waters, boiled water for Margaret Kochamma and Sophie Mol, as they are English men, and uncooked water for non English men. Mentally, they are shaped to do so, to treat English men better than their own. That case is also everyday racism. Indirectly, Indians have a mental racism, becuase racism is not only physical discrimination, but also mental discrimination. It shows that Ammu is felt uncomfortable when she deal with an English man, involving her sister in law, Margaret Kochamma.

\section{Racism in India (the upper class to the lowest class)}

As what I explained in previous discussion, I try to discuss racism happened between European race and Asian race, especially India in the real life. Then in the novel itself there is also the issue of racism within India that is the upper class as the superior and the lowest class considered as the inferior. The upper class in this thesis is called as touchable and the lowest class is called untouchable or paravan. Paravan is the lowest class in India and underistimated by people who come from upper class. Generally, racism happens in differentiations of skins color, but what happened from 1969 up to now is wider and complex. Wolf (2018) states that race is a socially constructed history that dividing people into two categorizations, those are visual and biological differences. But these categorizations are formless and transformed over time which reflects their social rather than physical basis. It means that the racism that occurs nowadays is not only limited to skin color differences, but also non-visual differences such as the social class differences It means that the racism that occurs nowadays is not only limited to skin color differences, but also non-visual differences such as the social class differences. 
That statement is connected with subchapter because here, I will focus more on discussing racism that happen between Indians with caste or social class differences. These statements will be supported by several quotations in the novel.

"Though Ammu, Estha and Rahel were allowed to attend the funeral, they were made to stand separately, not with the rest of the family. Nobody would look at them" (TGST:6).

...

"He spoke the coarse Kottayam dialect of Malayalam. He stared at Ammu's breasts as he spoke. He said the police knew all they needed to know and that the Kottayam Police didn't take statements from veshyas or their illegitimate children. Ammu said she'd see about that. Inspector Thomas Mathew came around his desk and approached Ammu with his baton" (TGST:8).

According to Oxford Advanced Learner's Dictionary "racism is unfair treatment or dislike of somebody because they are of a different race". The quotation above clearly said that Ammu, Estha and Rahel were separated from the family. They received unequal treatment from their families, because of their different social status. Inspector Thomas Mathew, an officer of police did the same act to Ammu, by being so rude to her and insult her.

If a husband dies, it makes a transition from the status of a wife to be a widow. Change the position of women from the main place in the family to the worst place. Since then she was considered to be physically living but socially dead. This declaration focuses on the status of widows in India where they are discriminated, oppressed, and excluded from all parts of life. A widow in India has responsibility for her husband's fate. If her husband dies, the wife is considered to have made a mistake in the past so that make her husband die. A widow in India was deported and harassed. They are considered to have no power or are considered socially dead, but their bodies still live in the world. Since Ammu got divorce with her ex-husband, Ammu's status was automatically a widow and became a widow in India is a taboo. Being a widow for Indians is a shame, people often discriminate a widow, even their family too.

"He walked past the village school that his great-grandfather built for Untouchable children". "Past Sophie Mol's yellow church.Past the Ayemenem Youth Kung Fu Club. Past the Tender Buds Nursery School (for Touchables), past the ration shop that sold rice, sugar and bananas that hung in yellow bunches from the roof. Cheap soft-porn magazines about fictitious South Indian sex-fiends were clipped with clothes pegs to ropes that hung from the ceiling. They spun lazily in the warm breeze, tempting honest ration-buyers with glimpses of ripe, naked women lying in pools of fake blood" (TGST:16).

In this citation, it is clear that there is gap between touchable and untouchable. Indians adhere to the human grouping system. All religions, all places that belong to India, all things in India are grouped into several groups. This division makes one group higher and the other 
group becomes lower. Even though India adheres to a democratic system, social equality is rarely found in everyday life. Hierarchical systems occur in social life in India. Grouping castes is usually attached to Hinduism. But in India, the caste system is also found in all religions. With the existence of public places built based on their class, it is very clear that there is unfair treatment among them, untouchable which is always underestimated and despicable.

"Perhaps Ammu, Estha and she were the worst transgressors. But it wasn't just them. It was the others too. They all broke the rules. They all crossed into forbidden territory. They all tampered with the laws that lay down who should be loved and how. And how much. The laws that make grandmothers grandmothers, unclesuncles, mothersmothers, cousins cousins, jam jam, and jelly jelly. It was a time when uncles became fathers, mothers lovers, and cousins died and had funerals. It was a time when the unthinkable became thinkable and the impossible really happened" (TGST:31).

The quotation above shows that Ammu and her children, and others, break the social and cultural rules. They had been so far to take a step. When Ammu got married and did not survive the relationship, Ammu's status became worse than before. The taboo here is about the chosen choice, Ammu choses to get divorce, and a divorce in India is something that most people in there avoid. Beside, Ammu's exhusband, Baba, is coming from the lower social status than Ammu. So, when Ammu gets divorce, her status as a widow cannot be accepted by her family. Not even Ammu herself, her children also get its consequences as children of divorced parents.

\section{The Social Condition in Indian Society}

Based on Foucault, things mean something and "true", only within a specific historical context. He thought that different historical contexts would not produce the same phenomenon. Foucault thinks that discourse produces a form of knowledge, which differs radically from period to period (Hall, 1997:46). It means that investigating the social condition in India at that time leads to know about the critical position and also helps to know about racism in India. Therefore, the social condition in India needs to explain here.

One of Great Britain's most vital colonies was India, approximately in the mid eighteenth century. The Great Britain's sources of raw materials were relied on India. They got supplies for the raw materials from this country in such a huge number and sent them to their country. The vast supplies they got from India were tea and cotton. It was begun in 1757, the East India Company ruled India. This organization was overseen by the British goverment and was successfully roled the system for hundred years. Unfortunately, in 1857, when the Sepoy Rebellion occured, they were successfully revolted against the British East India Company. Beside the chaos, The Sepoys rebellion, who were Moslem and Hindu, felt in upset knowing that the British used beef and pork to seal the rifle cartridges, as cows and pigs were forbidden in Islam and Hindu. The battles between the Sepoys and the East India Company resulted in a very tragic chaos, there were a lot of victims coming from both of groups. This 
war happened for almost a year. At last, the Sepoys' strunggle was succeed, they defeated East India Company and regained control of East India Company. (Nineteenth Century Colonialism in India, 2001).

While Great Britain felt that they were being very generous to the Indian people in colonizing and modernizing the nation, the Indians did not always agree with this. It is also shown in The God of Small Things.

"Over coffee Mr. Hollick proposed that Baba go away for a while. For a holiday. To a clinic perhaps, for treatment. For as long as it took him to get better. And for the period of time that he was away, Mr. Hollick suggested that Ammu be sent to his bungalow to be "looked after".

"When his bouts of violence began to include the children, and the war with Pakistan began, Ammu left her husband and returned, unwelcomed, to her parents in Ayemenem" (TGST:83).

The quotation above shows the form of protest from Ammu. When Baba told Ammu that Mr. Hollick asked Baba to send Ammu to his bungalow, she did not immediately approve the request even though Mr. Hollick considered as the superior. Ammu chose to leave her husband and return to his parent's house in Ayemenem.

The colonialism effects in 19th century still appear today. These effects, can be felt on different culture in there. After the colonization by Great Britain, India's culture changed, some of them were transforming. This situation led to a massive and foreign diversity of mixing culture between India and Great Britain. That happened because many people from India prefer to move to Great Britain. As a proof, we know that several famous Bollywood films are taken from several scenes in the Great Britain, such as Kuch Kuch Hota Hai, Kabhi Khushi Kabhie Gham, Mohabbatein and etc.

Many differences in India such as races, skin colours, genders and religions become a separator between European and Asian. Besides that, the problem of racism also existed within the blackwhich is the upper class considered as the superior, and the lower class as the inferior. In the nineteenth century India offers surprising variety in virtually every aspect of social life. Diversities of ethnic, linguistic, regional, economic, religious, and caste groups crosscut Indian society, which is also permeated with differences of gender distinctions. The position of women in the society was worst and tragic. They were abandoned, burnt alive, killed as soon as born, married at the 6 to someone 80 years old. Traditionally, males have an authority to family resources, such as land or businesses, especially in high-status groups. Following traditional Hindu law, women did not inherit real estate and were thus beholden to their male kin who controlled land and buildings.Indian women at that time were not educated.

Caste system and untouchability were other obstacles which were a great hurdle in the progress of India to be nation. The reformers had an idea that without getting rid of these two, there was no advancement possible (Jacobson, 2019). Castes are primarily associated with Hinduism, but caste-like groups also exist among Muslims, Indian, Christians, and other 
religious communities. Generally, high status is associated with purity and low status with pollutions. Some kinds of purity are inherent; for example, a member of a Brahmin is born with more inherent purity than someone born into a low caste like Untouchable. Many castes are associated with traditional occupations, like priests, barbers, carpenters, leatherworkers, butchers, and launderers. Members of higher castes tend to be more prosperous than members of lower castes. Most Indians reside in villages, where caste and class affiliations overlap. Large landowners are people of high caste, and small-scale farmers are in the middle caste, while landless workers usually belong to the lowest caste. These groups tend to form a system of stratification in rural areas, and members of these groups gather together in certain regions and distance themselves from the lower castes to increase their economic and political power

\section{The Critical Position of The Author Toward The Racism in}

The God of Small Things is an Indian novel. It is written in 1992 but the novel's setting time is around 1969 till 1993. This novel is written by an Indian writer named Arundhati Roy. Her full name is Suzanna Arundhati Roy, born on November 24, 1961 in Meghalaya, India and lived in Kerala when she was a child. She is an Indian writer, actress and political activist who are famous for the The God of Small Things' novel (1997) and because of her involvement in environmental and human rights issues. As part of Indian society, Roy is automatically positioned as part of the discourse in India. She wrote the novel with various problems in it, one of them was the problem of racism. The problem of racism does occur in real life in India, because India is a British colony in the 19th century, even today the equality of treatment of all Indian communities is rather difficult to find.

Roy's father was a tea planter from Bengali, and her mother was Christian Syria who opposed the applicable inheritance laws. She succeeded in suing the right of Christian women to receive an equal share of their ancestral land. Roy is active in various environmental and human rights issues, which makes her often put herself at odds with Indian legal authorities and the country's middle-class companies (Tikkanen, 2019). After I studied, most of the stories in the novel were the same as Roy's real life. Since childhood, Roy began to get used to a rebellion, so it is not surprising that nowadays she becomes an activist in defending human rights. Foucault states in Stuart Hall's book that:

"Things meant something and were 'true', he argued, only within a specific historical context. Foucault did not believe that the same phenomena would be found across different historical periods. He thought that, in each period, discourse produced forms of knowledge, objects, subjects and practices of knowledge, which different radically form period to period, with no necessary continuity between them" (Hall, 1997:46).

Based on the statement above, it means that the same phenomena in different historical context in different period may represent different discourse produced truly or wrongly in such knowledge, objects, and practice of knowledge.

This subchapter will show whether the authors agree or disagree about racism. Based on the story in the novel it can be assumed that Roy against the racism. The author positioned 
as a part of Indian society which is in her literary work, she is inspired by the surroundings. The novel tells about the social condition in Kerala, India. This story explains about the racism between European race and Asian race, and in Asian race itself especially in India. It tells that the people in Kerala viewed the British as superior. Besides that, they are also distinguished by caste system which Christian Syria is considered as the superior and the lowest caste of Hindu or the paravan is considered as the inferior. The Indian's way of thinking is trapped in a hierarchical system formed since the colonial period. They consider themselves inferior to westerners. other than that, as we know that India is known for its differentiated society based on each caste. Caste separates humans into social strata with different levels. People in the highest castes always underestimate those people in the lowest caste. The God of Small Things tells that the highest caste is Christian Syiria, and the lowest caste is Untouchable or Paravan. The caste system greatly influences a person's position at work. Generally untouchable only works as laborers or unskilled workers. Not only that problem, social status and gender also affects a person's life. A widow will also be underestimated even though she is from the high class. Women also don't need to be highly educated.

The problems that arise in the novel generally are about racism, oppression of lower class people. But Roy also create some characters who against racism.

"Their demands were that paddy workers, who were made to work in the fields for eleven and a half hours a day-from seven in the morning to six-thirty in the eveningbe permitted to take a one-hour lunch break. That omen's wages be increased from one rupee twenty-five paisa a day to three rupees, and men's from two rupees fifty paisa to four rupees fifty paisa a day. They were also demanding that Untouchables no longer be addressed by their caste names. They demanded not to be addressed as Achoo Parayan, or Kelan Paravan, or Kuttan Pulayan, but just as Achoo, or Kelan or Kuttan" (TGST:69).

The quotation above stated a request to get better rights. They protested the duration of work, the wages of female workers, also protested not to be addressed as Achoo Parayan, or Kelan Paravan, or Kuttan Pulayan which is the lowest caste in India. It means that Roy protested inequality through her literary work.

"Nothing specifically as such," Comrade K. N. M. Pillai said. "But see, comrade, any benefits that you give him, naturally others are resenting it. They see it as a partiality. After all, whatever job he does, carpenter or electrician or whateveritis, for them he is just a Paravan. It is a conditioning they have from birth. This I myself have told them is wrong. But frankly speaking, comrade, Change is one thing. Acceptance is another. You should be cautious. Better for him you send him off." "My dear fellow," Chacko said, "that's impossible. He's invaluable. He practically runs the factory- and we can't solve the problem by sending all the Paravans away. Surely we have to learn to deal with this nonsense" (TGST:279). 
Chacko was born as a Christian Syria, who automatically became a hight class person. But in this novel, Chacko employs Velutha, a paravan as an important part of the Mammachi factory. He refused to fire Velutha even though many people urged him to get fired immediately because as carpenters were too good for Velutha. Chacko opposed the rule which said that a Paravan only deserved to work as a laborer. It also form of Roy's protested that people from the lowest caste are also have the same right to get the same job as other castes.

From several quotes above, it can be seen that Roy against racism that happen in India. Roy in the real life is a Christian Syiria which is in the novel Christian Syiria is a highest class. But, she tries to push the lowest class to get the equality. It means that Roy against the racism through her literary work and she highlight that all human being are the same and have to treat equally.

\section{CONCLUSION}

This research generally divides racism in the novel into two types of racism. Racism that occurred in the novel is between Asian race and European race where European race was considered superior, and in Asian race (India) it self also emerged racism issues that occurred between the upper class of Indian society (touchable) and the lower class of Indian society (Untouchable/Paravan) where Paravan was considered inferior. This research uses representation theory by Stuart Hall. Using representation theory, the structure of the novel, the structure of the society in the real life, and the critical position of the author has been analyzed. This analysis produces the same discourse between the novel and the context representing racism in India.

Roy as the author of The God of Small Things tries to criticize the condition in India through her literary work. Roy in the real life was born as Christian Syria where Christian Syria belongs to the upper class. But in the novel, Roy create a character who tried against the racism, opposed the rules that prevailed in India at the time, and break down the rule of the upper class. From the analysis that has been done, Roy tried to protest the rules that intimidated the lower class, she demands the equality of all human beings, without seeing their caste. It can be concluded that Roy does not agree with racism that occurred in India.

\section{BIBLIOGRAPHY}

Beatty, M. 2018. Colour me right: It's time to end colourism in India. https://www.aljazeera.com/indepth/opinion/colour-time-colourism-india180906101053056. html. Accessed on June $20^{\text {th }} 2019$.

Grosfoguel, R. 2016. What is Racism? California: University of California.

Hall, S. 1997. Representation: Cultural Representation and Signifying Practices. London: Sage Publication.

Howarth, C. 2011. Representations, Identity and Resistance in Communication. London: London School.

Jacobson, D. 2019. Indian Society and Ways of Living. https://asiasociety.org/education/indian-society-and-ways-living. Accessed on June $12^{\text {th }} 2019$. 
Jhajharia, S. 2018. Arundhati Roy's The God of Small Things: An Indictment of Patriarchy, Caste System and Christianityna. Rajasthan: Mody University of Science and Technology.

Nineteenth Century Colonialism in India. 2001. Reasons for Colonialisms.http://www2.needham.k12.ma.us/nhs/cur/Baker00/2001p4/bakermrrlp4/ colonialism.htm. Accessed on June $10^{\text {th }} 2019$.

Roy, A. 1997. The God of Small Things. India: Indialnk.

Tikkanen, A. 2019. Arundhati Roy Indian Author, Actress, and Activist. https://www.britannica.com/biography/Arundhati-Roy. Accessed on July $6^{\text {th }} 2018$.

Tyson, L. 2006. Critical Race Theory Today. New York: Taylor \& Francis Group.

Warda. 2017. Racism Faced by Minette Swift in Joyce Carol Oates'sBlack Girl/White Girl. Jember: Jember University Press.

Winahyu, G. 2017. The Representation of Woman's oppression Through the Female Main Character in Zana Muhsen With Andrew Crofts's Sold. Jember: Jember University Press.

Wolf, R. 2018. Race and Racism Illumination Project Curriculum Materials. https://www.pcc.edu/illumination/wpcontent/uploads/sites/54/2018/05/race-andracism-curriculum.pdf. Accessed on January $14^{\text {th }} 2019$. 